\title{
Organic carbon and nitrogen contents and their isotopic compositions in surficial sediments from the East China Sea shelf and the southern Okinawa Trough
}

\author{
S.J. Kao ${ }^{\mathrm{a}, *}$, F.J. Lin ${ }^{\mathrm{b}}$, K.K. Liu ${ }^{\mathrm{b}, \mathrm{c}}$ \\ ${ }^{a}$ Environmental Change Research Center, Academia Sinica, P.O. Box 1-55, Nankang, Taipei, Taiwan \\ ${ }^{\mathrm{b}}$ Institute of Oceanography, National Taiwan University, Taipei, Taiwan \\ ${ }^{\mathrm{c}}$ National Center for Ocean Research, Taipei, Taiwan
}

Accepted 12 December 2002

\begin{abstract}
The southern Okinawa Trough has been noted as an important depocenter for the particulate organic matter from the East China Sea shelf. In order to determine the major sources of sedimentary organic matter in the southern Okinawa Trough, we analyzed surficial sediments from the East China Sea shelf and the southern Okinawa Trough for organic carbon and nitrogen contents and their isotopic compositions in the decarbonated fraction. Distributions of total organic carbon content, $\delta^{13} \mathrm{C}_{\mathrm{org}}$ and nitrogen content all show a similar spatial pattern, resembling the distribution of fine-grained sediments. The coastal belt of elevated organic carbon content extends southward from the Changjiang mouth and veers offshore towards the southern Okinawa Trough just north of Taiwan, implying a pathway for channeling fine-grained sediments from the inner shelf to the depocenter. This distribution pattern is consistent with the shelf circulation. The isotope compositions $\left(\delta^{13} \mathrm{C}_{\mathrm{org}}, \delta^{15} \mathrm{~N}\right)$ of sediments from the southern Okinawa Trough fall between those of riverine particulate organic matter and the mid-outer shelf sediments, but overlap with those of the inner shelf sediments. In addition, the previously reported $\delta^{13} \mathrm{C}_{\text {org }}$ values of sinking particles collected by sediment traps in the southern Okinawa Trough are also close to those of the inner shelf sediments, especially during high-flux conditions. Therefore, the isotopic evidence strongly supports the notion that a major fraction of the sedimentary organic matter in the southern Okinawa Trough may originate from the inner shelf.
\end{abstract}

(C) 2003 Elsevier Science Ltd. All rights reserved.

\section{Introduction}

The East China Sea (ECS; Fig. 1) is one of the largest marginal seas in the world, which has moderately high primary production

*Corresponding author. Tel.: +886-2-27839910 × 809; fax: + 886-2-2783-9871.

E-mail address: sjkao@earth.sinica.edu.tw (S.J. Kao).
(108-997 $\mathrm{mg} \mathrm{m}^{-2} \mathrm{~d}^{-1}$ with a mean value of $425 \mathrm{mg} \mathrm{m}^{-2} \mathrm{~d}^{-1}$; Gong et al., 2003). It has been estimated that ECS may adsorb $20-30 \mathrm{Mt} \mathrm{CO}_{2}-$ $\mathrm{Cy}^{-1}$ mostly in the inner and middle shelves adjacent to the Changjiang River mouth (Peng et al., 1999; Tsunogai et al., 1999; Wang et al., 2000), which is considerably larger than the estimated flux of organic carbon burial in the shelf sediments $\left(10 \mathrm{Mt} \mathrm{Cy}^{-1}\right.$; Chen and Wang, 


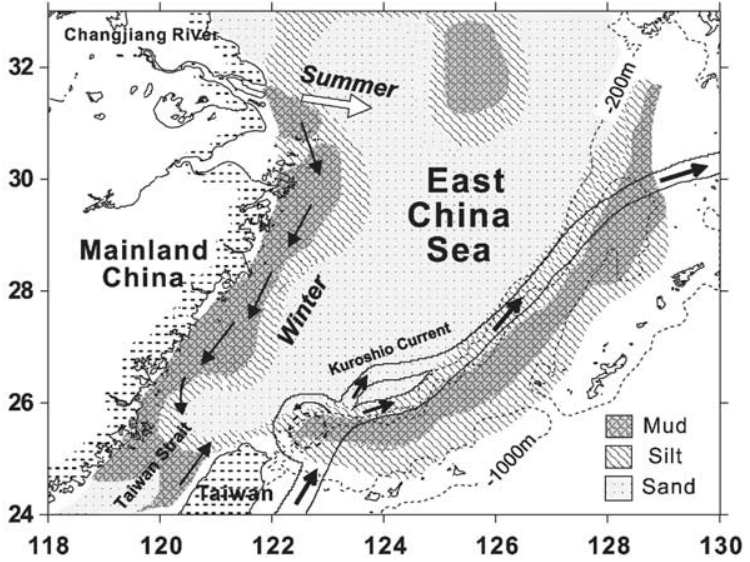

Fig. 1. Flow pattern and sediment grain size distribution in the East China Sea shelf (after Liu et al, 2000). Arrows along the China coast represent the Changjiang runoff during summer (open arrow) and winter (solid arrows). The main stream of the Kuroshio Current is shown in solid curves. A dashed circle represents the upwelling center induced by a cyclonic eddy located at the northeast off Taiwan. The grain size distribution pattern is after Zhao and Yan (1994). Iso-contour lines of water depth of 200 and $1000 \mathrm{~m}$ are in dashed curves.

1999). Apparently, a major fraction of absorbed carbon must be exported out of the ECS shelf to balance the carbon budget. One of the possible mechanisms is the cross-shelf export of particulate organic matter (POM). The most likely site for deposition of exported POC from the ECS is the Okinawa Trough, which is located at the seaward edge of the shelf (Fig. 1). However, sediment deposition rates, carbon accumulation rates and POC fluxes in the Okinawa Trough are highly uneven spatially. Plenty of evidence indicates that the southern Okinawa Trough (SOT) is an important site for POC export from the shelf.

In the SOT region, sedimentation rates (Chung and Chang, 1995; Chen, 1995) reach 0.10$0.95 \mathrm{~cm} \mathrm{y}^{-1}$; which are more than 10 times higher than those observed in the northern and central trough $\left(<0.01-0.08 \mathrm{~cm} \mathrm{y}^{-1}\right.$; Ikehara, 1995). The observed POC fluxes from the trap deployed in the SOT area (Stations marked by $\mathrm{T}$ in Fig. $2 \mathrm{~b}$ ) range from 10 to $750 \mathrm{mg} \mathrm{C} \mathrm{m}^{-2} \mathrm{~d}^{-1}$ (Chung and Chang, 1995; Sheu et al., 1999; Chung and Hung, 2000), which are significantly higher than those $(<40 \mathrm{mg}$
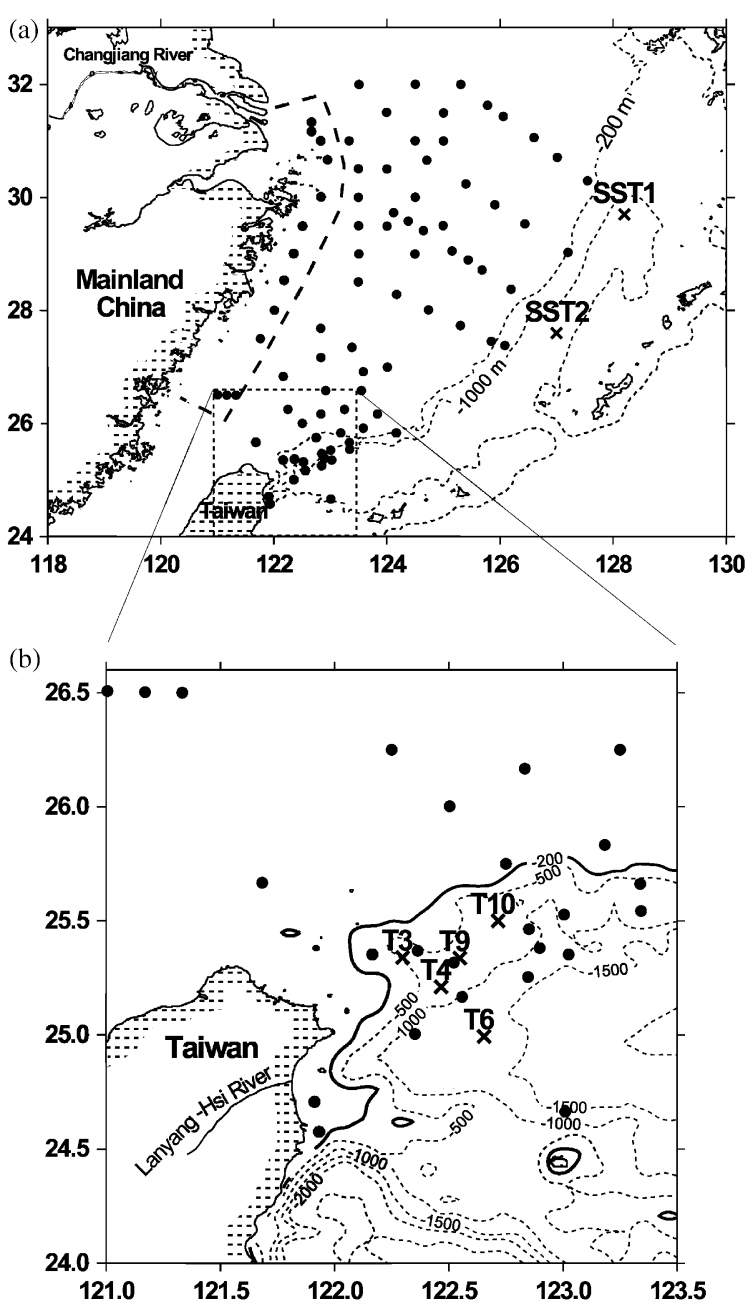

Fig. 2. Map of sediment sample locations (dots): (a) in the East China Sea and (b) in the southern part of the Okinawa Trough. Also marked are the two sediment trap stations, $\mathrm{SST}_{1}$ and $\mathrm{SST}_{2}$ reported by Minagawa and Kadota (1994) and those $\left(\mathrm{T}_{3}-\mathrm{T}_{10}\right)$ reported by Sheu et al. (1999). Bold dashed-line stands for the inner-shelf area defined in this study. Water depth of $200 \mathrm{~m}$ is marked by solid curve.

$\mathrm{C} \mathrm{m}^{-2} \mathrm{~d}^{-1}$; Iseki et al., 1995) obtained by traps of the Marginal Sea Flux Experiment (MASFLEX) deployed in the central and northern trough (Stations marked by $\mathrm{SST}_{1}$ and $\mathrm{SST}_{2}$ in Fig. 2a). For a longer term, the organic carbon accumulation rate has been estimated in the range of $5-56 \mathrm{~g}$ $\mathrm{C} \mathrm{m}^{-2} \mathrm{y}^{-1}$ (Chen, 1995) in the SOT. Apparently, the SOT receives more particulate organic matter 
than other parts of the Okinawa Trough (Sheu et al., 1999; Hung et al., 1999; Liu et al., 2000).

Regarding the process responsible for feeding sediments to the SOT from the ECS shelf along the China coast, Liu et al. (2000) proposed a conceptual model illustrating the possible route of the sediment transport (Fig. 1). The fine-grained sediments from Changjiang tend to deposit along the south coast of the river mouth (McKee et al., 1983). During the northeast monsoon in winter, the China Coastal Current forms a southward jet flow, which moves the resuspended sediments southward along the coast (Beardsley et al., 1985; Chao, 1991). The sediments may be transported across the shelf in the northern Taiwan Strait due to the blocking of a topographic high in the middle section of the Strait (Jan et al., 1998) and a steady northward bottom current along the western coast of Taiwan (Chuang, 1985; see Fig. 1). As the main stream of the Kuroshio encounters the shelf break of the ECS, a cyclonic eddy forms off northeastern Taiwan, while the Kuroshio turns northeastward. It is the cyclonic eddy northeast of Taiwan, which may send the sediments offshore to the SOT.

In addition to sediments from the ECS shelf, sediments from Taiwan (Hsu et al., 1998) as well as primary production in the water column (Liu et al., 1995) are also potential sources of sedimentary organic matter in the SOT. The purpose of this study is to determine which of the potential sources is most important. For this purpose, we use dual isotope compositions $\left(\delta^{13} \mathrm{C}\right.$ and $\delta^{15} \mathrm{~N}$ ) as tracers (Peters et al., 1978; Willians et al., 1992; Thornton and McManus, 1994; Middelburg and Nieuwenhuize, 1998) to elucidate the origins of sedimentary organic matter in the SOT. The total organic carbon content (TOC\%), nitrogen content (TN\%) and their isotopic compositions were analyzed for samples from a wide region in the ECS shelf and the SOT covering depths from 50 to $1500 \mathrm{~m}$ (Fig. 2). We also drew data from previous studies of sedimentary organic carbon (Lin et al., 1992; Chen, 1992) and settling particulate organic carbon (Sheu et al., 1999) in the ECS shelf and adjacent areas for the discussion.

\section{Materials and methods}

In this study we analyzed 71 surficial sediment samples from the ECS shelf (Fig. 2a i Table 1) and 14 samples from the SOT region (Fig. 2b), which were collected with a box corer on R/V Researcher-1 cruises between 1992 and 1996 and with a Van-Veen type grab on the R/V Vinogradov cruise KEEP-MASS in 1992. Sub-samples from the box cores were obtained with plastic tubings with an inner diameter of $5.3 \mathrm{~cm}$ and a length of $60 \mathrm{~cm}$. Sealed samples were then preserved in a freezer. After taken to the laboratory, surficial sediments were scraped from the top $2 \mathrm{~cm}$ of the sealed samples with a stainless steel spatula, stored in plastic vials, and then placed in a freeze-drier for one week. The dried sediments were later ground to powder with pestle and mortar prior to analysis.

Carbon and nitrogen isotope samples were prepared using sealed-tube combustion method (Wedeking et al., 1983). About $0.2 \mathrm{~g}$ powdered sediments was acid-treated with $1 \mathrm{~N} \mathrm{HCl}$ for 3 days in pre-combusted $\left(500^{\circ} \mathrm{C}\right)$ glass test-tubes to remove carbonate. They were then centrifuged for removal of solution and the acid-treated sediments were further dried at $60^{\circ} \mathrm{C}$. Acidified samples were mixed with $1 \mathrm{~g}$ each of $\mathrm{CuO}, \mathrm{Cu}$ pellets and several inches of silver wire, and then sealed in evacuated 9-mm quartz tubes. Quartz tubes were then heated at $900^{\circ} \mathrm{C}$ for $3 \mathrm{~h}$, kept at $650^{\circ} \mathrm{C}$ for over $12 \mathrm{~h}$, and cooled to room temperature. $\mathrm{N}_{2}$ and $\mathrm{CO}_{2}$ gases were extracted and purified in a vacuum line and collected in sealed $6-\mathrm{mm}$ glass tubes. The abundances of carbon and nitrogen were measured manometrically in the vacuum line and presented in percentage. This method had been crosschecked previously by LECO Carbon Analyzer and gave consistent results (RSD $<5 \%$; Chang et al., 1991). The adsorbed $\mathrm{NH}_{4}^{+}$was generally eliminated during our pretreatment; yet the $\mathrm{NH}_{4}^{+}$fixed in the clay could not be removed. Therefore, the measured nitrogen may have included both organic and inorganic forms and is referred to as total nitrogen $(\mathrm{TN})$ in this study. Carbon and nitrogen isotopic compositions were determined in a Micromass VG602E mass spectrometer. Results are presented in the standard $\delta$ notation with 
Table 1

Sampling location, overlying water depth, total organic carbon, total nitrogen and isotopic compositions

\begin{tabular}{|c|c|c|c|c|c|c|c|}
\hline No. & Water depth & Lat. & Long. & TOC \% & $\mathrm{TN} \%$ & $\delta^{15} \mathrm{~N}$ & $\delta^{13} \mathrm{C}$ \\
\hline \multicolumn{8}{|c|}{ Inner-shelf sediments } \\
\hline 1 & 42 & 31.33 & 122.67 & 0.48 & 0.065 & 4.1 & -22.4 \\
\hline 2 & 38 & 31.17 & 122.67 & 1.31 & 0.170 & 3.6 & -22.2 \\
\hline 3 & 32 & 31.00 & 122.83 & 0.52 & 0.067 & 3.8 & -21.7 \\
\hline 4 & 48 & 30.01 & 122.84 & 0.67 & 0.099 & 4.5 & -22.2 \\
\hline 5 & 40 & 29.49 & 122.51 & 0.67 & 0.089 & 4.3 & -22.3 \\
\hline 6 & 45 & 29.01 & 122.35 & 0.63 & 0.086 & 4.4 & -22.3 \\
\hline 7 & 45 & 28.53 & 122.18 & 0.96 & 0.130 & 4.0 & -22.4 \\
\hline 8 & 48 & 28.00 & 122.01 & 0.73 & 0.100 & 4.1 & -22.4 \\
\hline 9 & 55 & 27.50 & 121.76 & 0.78 & 0.104 & 4.3 & -22.1 \\
\hline 10 & 70 & 26.51 & 121.01 & 0.88 & 0.130 & 3.9 & -22.1 \\
\hline 11 & 72 & 26.50 & 121.17 & 0.48 & 0.070 & 3.5 & -22.3 \\
\hline 12 & 78 & 26.50 & 121.33 & 0.46 & 0.065 & 3.9 & -21.9 \\
\hline 13 & 135 & 25.67 & 121.68 & 0.42 & 0.062 & 4.1 & -22.1 \\
\hline \multicolumn{8}{|c|}{ Middle-outer shelf sediments } \\
\hline 14 & 49 & 30.67 & 122.95 & 0.53 & 0.082 & 4.2 & -21.2 \\
\hline 15 & 36 & 32.00 & 124.50 & 0.37 & 0.051 & 4.5 & -20.0 \\
\hline 16 & 51 & 32.00 & 125.31 & 0.57 & 0.082 & 5.1 & -21.1 \\
\hline 17 & 37 & 32.00 & 123.51 & 0.13 & 0.018 & 3.9 & -20.3 \\
\hline 18 & 60 & 31.63 & 125.78 & 0.78 & 0.116 & 5.0 & -21.1 \\
\hline 19 & 39 & 31.50 & 123.99 & 0.19 & 0.027 & 4.5 & -19.8 \\
\hline 20 & 44 & 31.50 & 125.00 & 0.40 & 0.059 & 4.5 & -21.0 \\
\hline 21 & 67 & 31.43 & 126.06 & 0.64 & 0.099 & 4.5 & -21.2 \\
\hline 22 & 86 & 31.06 & 126.60 & 0.52 & 0.078 & 5.1 & -20.9 \\
\hline 23 & 47 & 31.00 & 124.50 & 0.29 & 0.045 & 5.2 & -20.1 \\
\hline 24 & 56 & 31.00 & 123.33 & 0.22 & 0.030 & 4.2 & -19.9 \\
\hline 25 & 55 & 31.00 & 125.00 & 0.44 & 0.065 & 4.8 & -20.7 \\
\hline 26 & 96 & 30.71 & 127.01 & 0.47 & 0.062 & 4.6 & -20.7 \\
\hline 27 & 53 & 30.66 & 124.71 & 0.23 & 0.036 & 4.2 & -20.6 \\
\hline 28 & 54 & 30.51 & 123.50 & 0.30 & 0.042 & 3.8 & -20.1 \\
\hline 29 & 50 & 30.50 & 124.00 & 0.28 & 0.042 & 4.6 & -20.1 \\
\hline 30 & 128 & 30.29 & 127.55 & 0.25 & 0.035 & 4.8 & -20.5 \\
\hline 31 & 69 & 30.24 & 125.40 & 0.25 & 0.049 & 4.0 & -20.8 \\
\hline 32 & 62 & 30.00 & 124.50 & 0.29 & 0.044 & 4.3 & -20.5 \\
\hline 33 & 64 & 30.00 & 123.50 & 0.40 & 0.057 & 4.3 & -20.4 \\
\hline 34 & 77 & 29.87 & 125.91 & 0.31 & - & - & -20.5 \\
\hline 35 & 60 & 29.73 & 124.12 & 0.24 & 0.037 & 4.6 & -20.2 \\
\hline 36 & 70 & 29.58 & 124.38 & 0.27 & 0.040 & 4.9 & -20.6 \\
\hline 37 & 100 & 29.53 & 126.44 & 0.24 & 0.039 & 4.9 & -20.6 \\
\hline 38 & 85 & 29.50 & 125.00 & 0.48 & 0.068 & 4.5 & -20.5 \\
\hline 39 & 65 & 29.50 & 123.50 & 0.40 & 0.059 & - & -20.0 \\
\hline 40 & 73 & 29.49 & 124.00 & 0.37 & 0.056 & 4.7 & -20.4 \\
\hline 41 & 74 & 29.41 & 124.65 & 0.30 & 0.042 & 4.2 & -20.5 \\
\hline 42 & 78 & 29.05 & 125.15 & 0.23 & 0.034 & 4.7 & -20.0 \\
\hline 43 & 390 & 29.03 & 127.20 & 0.39 & 0.057 & 5.0 & -21.0 \\
\hline 44 & 67 & 29.00 & 123.51 & 0.36 & 0.053 & 4.1 & -20.4 \\
\hline 45 & 81 & 29.00 & 124.50 & 0.25 & 0.037 & 4.8 & -20.2 \\
\hline 46 & 85 & 28.89 & 125.44 & 0.36 & 0.050 & 4.2 & -20.9 \\
\hline 47 & 104 & 28.72 & 125.68 & 0.20 & 0.028 & 3.8 & -20.3 \\
\hline 48 & 67 & 28.51 & 123.50 & 0.25 & 0.036 & 4.0 & -20.6 \\
\hline 49 & 114 & 28.38 & 126.20 & 0.20 & 0.036 & 4.0 & -20.4 \\
\hline 50 & 84 & 28.28 & 124.17 & 0.25 & 0.037 & 4.9 & -20.6 \\
\hline
\end{tabular}


Table 1 (continued)

\begin{tabular}{|c|c|c|c|c|c|c|c|}
\hline No. & Water depth & Lat. & Long. & TOC $\%$ & TN $\%$ & $\delta^{15} \mathrm{~N}$ & $\delta^{13} \mathrm{C}$ \\
\hline 51 & 104 & 28.01 & 124.74 & 0.29 & 0.048 & 4.9 & -20.5 \\
\hline 52 & 101 & 27.73 & 125.30 & 0.16 & 0.032 & 4.9 & -20.2 \\
\hline 53 & 82 & 27.68 & 122.83 & 0.25 & 0.039 & 4.5 & -20.8 \\
\hline 54 & 123 & 27.45 & 125.85 & 0.07 & 0.014 & 6.1 & -19.7 \\
\hline 55 & 330 & 27.38 & 126.09 & 0.12 & 0.021 & 5.3 & -19.6 \\
\hline 56 & 104 & 27.35 & 123.38 & 0.22 & 0.035 & 5.2 & -20.4 \\
\hline 57 & 106 & 27.17 & 122.83 & 0.21 & 0.031 & - & -21.1 \\
\hline 58 & 121 & 27.00 & 124.01 & 0.17 & 0.026 & 5.1 & -20.1 \\
\hline 59 & 116 & 26.92 & 123.58 & 0.19 & 0.032 & - & -21.4 \\
\hline 60 & 97 & 26.83 & 122.17 & 0.18 & 0.026 & - & -21.0 \\
\hline 61 & 118 & 26.58 & 122.92 & 0.22 & 0.034 & - & -21.3 \\
\hline 62 & 134 & 26.58 & 123.55 & 0.26 & 0.042 & - & -20.3 \\
\hline 63 & 100 & 26.25 & 122.25 & 0.10 & 0.017 & - & -20.9 \\
\hline 64 & 126 & 26.25 & 123.25 & 0.14 & 0.019 & - & -20.4 \\
\hline 65 & 108 & 26.17 & 122.83 & 0.10 & 0.018 & - & -20.2 \\
\hline 66 & 136 & 26.17 & 123.83 & 0.15 & 0.027 & - & -20.5 \\
\hline 67 & 107 & 26.00 & 122.50 & 0.08 & 0.015 & 6.3 & -19.7 \\
\hline 68 & 133 & 25.92 & 123.58 & 0.14 & 0.021 & - & - \\
\hline 69 & 100 & 25.83 & 123.18 & 0.14 & 0.024 & - & -20.4 \\
\hline 70 & 194 & 25.83 & 124.17 & 0.15 & 0.022 & - & - \\
\hline 71 & 104 & 25.75 & 122.75 & 0.14 & 0.025 & - & -20.9 \\
\hline \multicolumn{8}{|c|}{ SOT sediments } \\
\hline$* 72$ & 52 & 24.71 & 121.91 & 0.52 & 0.070 & 4.1 & -23.4 \\
\hline$* 73$ & 115 & 24.58 & 121.93 & 0.49 & 0.069 & 3.9 & -24.1 \\
\hline 74 & 137 & 25.32 & 122.52 & 0.18 & 0.028 & 3.7 & -21.1 \\
\hline 75 & 380 & 25.35 & 122.17 & 0.31 & 0.045 & 4.0 & -21.4 \\
\hline 76 & 574 & 25.46 & 122.85 & 0.71 & 0.094 & 3.6 & -21.2 \\
\hline 77 & 786 & 25.53 & 123.01 & 0.75 & 0.110 & 3.8 & -21.2 \\
\hline 78 & 814 & 25.66 & 123.34 & 0.76 & 0.103 & 4.1 & -21.3 \\
\hline$* 79$ & 824 & 25.00 & 122.35 & 0.56 & 0.089 & 4.2 & -23.5 \\
\hline 80 & 831 & 25.25 & 122.85 & 0.72 & 0.100 & 3.6 & -21.6 \\
\hline 81 & 846 & 25.54 & 123.34 & 0.63 & 0.087 & 4.0 & -22.5 \\
\hline 82 & 886 & 25.38 & 122.90 & 0.75 & 0.110 & 3.8 & -21.7 \\
\hline 83 & 974 & 25.37 & 122.36 & 0.68 & 0.091 & 3.9 & -22.4 \\
\hline 84 & 1303 & 25.17 & 122.56 & 0.68 & 0.085 & 3.5 & -21.1 \\
\hline 85 & 1420 & 24.66 & 123.01 & 0.67 & 0.090 & 3.8 & -21.5 \\
\hline 86 & 1630 & 25.35 & 123.03 & 0.61 & 0.091 & 3.9 & -21.3 \\
\hline
\end{tabular}

Note: Symbol — stands for those samples influenced by Lanyang-Hsi river.

respect to standards of atmospheric nitrogen and PDB carbon. The precision of nitrogen and carbon isotopic determination for sediment samples is better than $\pm 0.2 \%$.

In the presentation of distributions of sedimentary organic carbon and its isotopic composition, we include previously reported data of TOC \% (from Lin et al., 1992) and $\delta^{13} \mathrm{C}_{\text {org }}$ (from Chen, 1992) for surface sediments in the SOT area to make the contour map more complete. Lin et al.
(1992) used $1 \mathrm{~N} \mathrm{HCl}$ to remove carbonate, dried the acidified samples in the oven at $50^{\circ} \mathrm{C}$, and then measured TOC with a LECO Carbon Analyzer. The results should be consistent with the vacuum extraction method according to the comparison study of Chang et al. (1991). Chen (1992) used 2.4 $\mathrm{N} \mathrm{HCl}$ to remove carbonate and then dried the acidified samples without removing the solution. It has been demonstrated that pre-treatments for decarbonation with or without removing the acid 
solution produced $\delta^{13} \mathrm{C}_{\mathrm{org}}$ values within $0.2 \%$ from each other (Kao et al., 2001). Similar results have also been reported by Schubert and Nielsen (2000).

Reported isotopic compositions of sinking particles collected at $\mathrm{SST}_{1}$ and $\mathrm{SST}_{2}$ from March 1993 to February 1994 (Fig. 2a) and at $T_{3}, T_{4}, T_{6}$, $\mathrm{T}_{9}$ and $\mathrm{T}_{10}$ from July 1993 to December 1995 (Fig. 2b) are included for discussion. The bottom depths at $\mathrm{SST}_{1}$ and $\mathrm{SST}_{2}$ were $1100 \mathrm{~m}$ and the trap depths were between 600 and $1050 \mathrm{~m}$ (Iseki et al., 1995). The bottom depths at Stations $T_{3}, T_{4}, T_{6}$, $\mathrm{T}_{9}$ and $\mathrm{T}_{10}$ range between 578 and $1440 \mathrm{~m}$, and the trap depths range between 378 and $1340 \mathrm{~m}$. Samples from sites $\mathrm{SST}_{1}$ and $\mathrm{SST}_{2}$ have dual isotope compositions (Minagawa and Kadota, 1994), while samples from the other sites were preserved with sodium azid and, therefore, were analyzed for $\delta^{13} \mathrm{C}_{\text {org }}$ values but not $\delta^{15} \mathrm{~N}$ values (Sheu et al., 1999).

\section{Results}

The distribution of TOC in surficial sediments on the ECS shelf from the Changjiang River mouth to the SOT (Fig. 3) shows that most of the shelf area has less than $0.4 \%$. TOC a strong seaward gradient appears in the inner shelf with higher TOC values $(>0.50 \%$; Fig. $3 \mathrm{a})$ near the coast; and the maximum value $(>0.9 \%)$ occurs near the Changjiang mouth. Outside the inner shelf TOC percentage decreases seaward in general and drops to less than $0.2 \%$ near the shelf break. Two areas with distinctively high TOC stand out against the generally low TOC background away from the coastal zone (Fig. 3a). One is located at the northeastern corner (around $32^{\circ} \mathrm{N} ; 126^{\circ} \mathrm{E}$ ) of the contour map and the other one is in the SOT.

The areas with TOC $>0.50 \%$ matches well the mud patches (Fig. 1) (Zhao and Yan, 1994; Qu and $\mathrm{Hu}, 1993 ; \mathrm{Hu}, 1984 ; \mathrm{Hu}$ et al., 1998). The coastal belt with elevated TOC content extends southward from the Changjiang mouth. It is noteworthy that this belt veers offshore and extends toward the SOT as it approaches the northern end of the Taiwan Strait. Lin and Chen (1996) also observed a similar spatial distribution

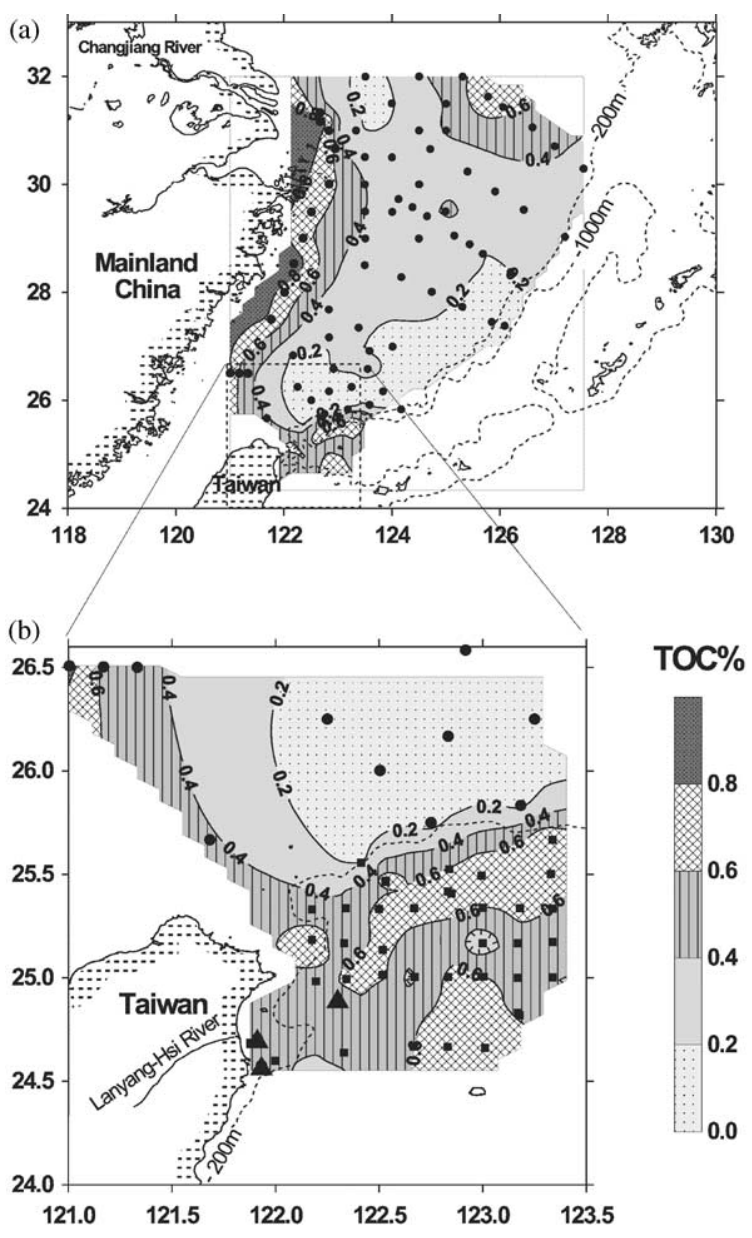

Fig. 3. Distribution of the organic carbon content (TOC\%) in sediments in (a) the East China Sea shelf and (b) the southern Okinawa Trough. Scales are the same for the two panels. Filled circles represent data from this study and squares represent data from Lin et al. (1992). The Lanyang-Hsi River, located at the northeastern Taiwan, is also shown. Three triangles locate the three samples affected by riverine sediments (see text).

for fine-grained sediments. It is likely that the seaward extension of this belt is connected with the high TOC zone in the SOT (Fig. 3b).

The Lanyang-Hsi River (Fig. 3b), which has a sediment discharge rate of $6-9 \mathrm{Mty}^{-1}$ (Kao and Liu, 2000), and other high sediment-yielding Taiwanese watersheds have been suggested as the main contributors of lithogenic materials to the SOT (Hsu et al., 1998). However, contrary to the high $\mathrm{TOC} \%$ found at the Changjiang mouth, the TOC\% off the Lanyang-Hsi River 


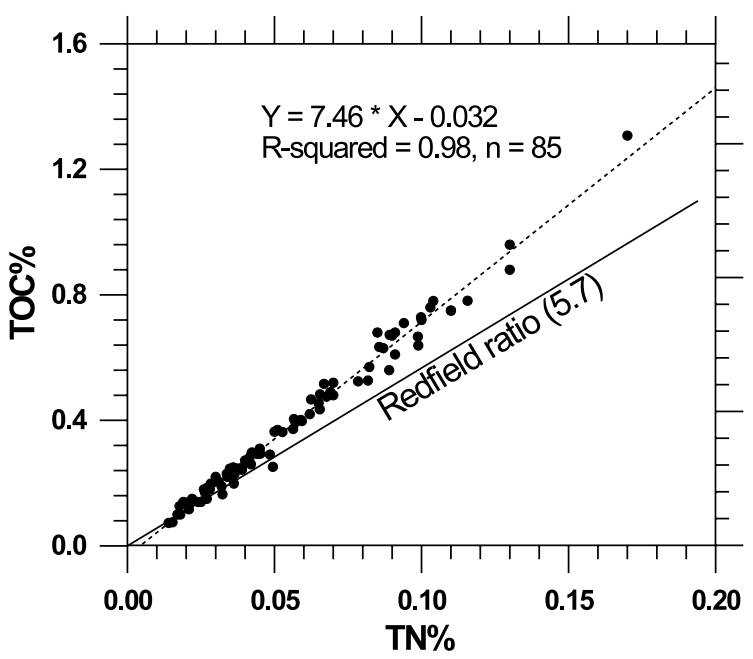

Fig. 4. The scatter plot of total organic carbon and nitrogen content in sediments. Redfield ratio of 5.7 (wt/wt) is shown in solid line. The dashed line represents the regression function.

mouth was rather low (Fig. 3b). The low TOC $\%$ indicates a strong mineral dilution effect, which is typical for the mountainous watersheds (Kao and Liu, 1996). Aside from the differences in TOC\%, it is shown later that the isotopic characteristics of the riverine POC also differ considerably from the sedimentary organic carbon in the SOT.

The spatial distribution pattern of total nitrogen (TN\%) in the decarbonated sediments (not shown) is quite similar to that of $\mathrm{TOC} \%$. The $\mathrm{TN}$ values range from $0.02 \%$ to $0.19 \%$ with the highest values occurring in the mud patches. The TN\% shows a strong linear correlation with TOC\% (Fig. 4) with a regression equation as follows:

$\mathrm{TOC} \%=7.46 \mathrm{TN} \%-0.03$

$R^{2}=0.98, p<0.001, n=85$.

The regression line almost passes through the origin, suggesting that most of the nitrogen measured by our method is related to sedimentary organic carbon and, therefore, probably in the organic form (Hedges et al., 1986). Fig. 4 also shows that sediments with high TOC contents have $\mathrm{C} / \mathrm{N}$ ratios higher than the Redfield ratio of 5.7 (wt/wt), while those with lower TOC contents have $\mathrm{C} / \mathrm{N}$ ratios approaching the Redfield ratio.
The elevated $\mathrm{C} / \mathrm{N}$ ratios in the coastal zone are consistent with higher contributions of organic matter from terrestrial sources, which usually show higher $\mathrm{C} / \mathrm{N}$ ratio $(\mathrm{C} / \mathrm{N}$ atomic ratio $>12$; Kukal, 1971; Aitkenhead and McDowell, 2000).

The $\delta{ }^{13} \mathrm{C}_{\mathrm{org}}$ values in surficial sediments show a rather large range, from $-25.0 \%$ to $-19.6 \%$. Most of the lower values $(-21.5 \%$. or less) occur in the coastal mud belt within about $100 \mathrm{~km}$ from the coast, and higher values in the middle and outer shelves (Fig. 5). The results are consistent with the findings of Tan et al. (1991) for Changjiang delta sediments and of Sheu et al. (1995) for middle and outer ECS shelf sediments. However, the data presented here over the entire shelf reveal an isotopic distribution pattern of sedimentary organic carbon has not previously shown. A belt with relatively low $\delta^{13} \mathrm{C}_{\text {org }}$ extends from the Changjiang River mouth southward along the coast and goes offshore near Taiwan. This isotopic distribution pattern is quite similar to that of TOC with only minor differences.

The lower $\delta^{13} \mathrm{C}_{\text {org }}$ values $(<-21.5 \%)$ in the inner shelf suggest a stronger influence of terrigenous organics, which has a typical endmember value of $-26.5 \%$ (e.g., Peters et al., 1978, Wada et al., 1987). The higher $\delta^{13} \mathrm{C}_{\text {org }}$ values more offshore generally suggest a higher fraction of marine organic matter, which has a typical endmember value of $-20.0 \%$ (e.g., Goericke and Fry, 1994). On the other hand, the relatively high $\delta^{13} \mathrm{C}_{\text {org }}$ in sedimentary organic matter could be attributed to $\mathrm{C}_{4}$ plants and it's degraded residuals (Goni et al., 1998; Onstad et al., 2000). However, the $\delta^{15} \mathrm{~N}$ values of the same samples (to be shown later) indicate the sedimentary organic matter in the mid-outer shelf more akin to marine origin than to $\mathrm{C}_{4}$ plants.

The surface sediments in the SOT showed relatively low $\delta^{13} \mathrm{C}_{\text {org }}$ values (Fig. $5 \mathrm{~b}$ ), consistent with the trend on the shelf that lower $\delta^{13} \mathrm{C}_{\text {org }}$ values associate with higher $\mathrm{TOC} \%$. It is noted that a different relationship between $\delta^{13} \mathrm{C}_{\text {org }}$ and TOC was found off the Lanyang-Hsi River mouth, where the lowest $\delta^{13} \mathrm{C}_{\text {org }}$ values $(<-23 \%$, Fig. $5 \mathrm{~b})$ did not correspond to high TOC $\%$ values but to relatively low values $(<0.5 \%$, Fig. $3 b)$. This is 


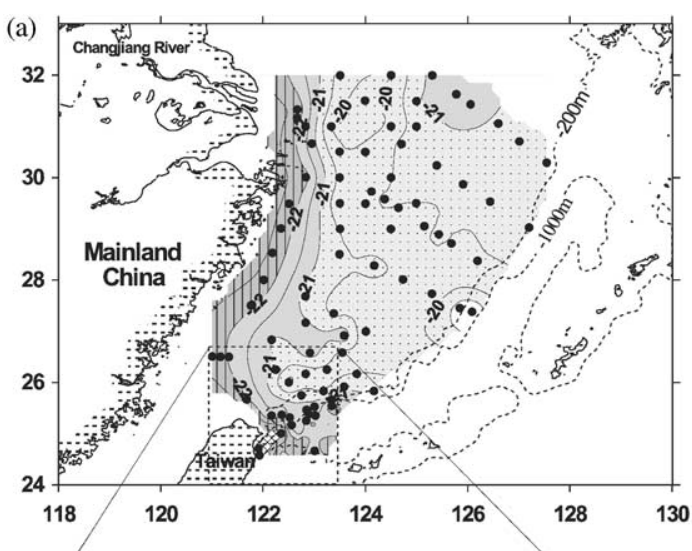

(b)

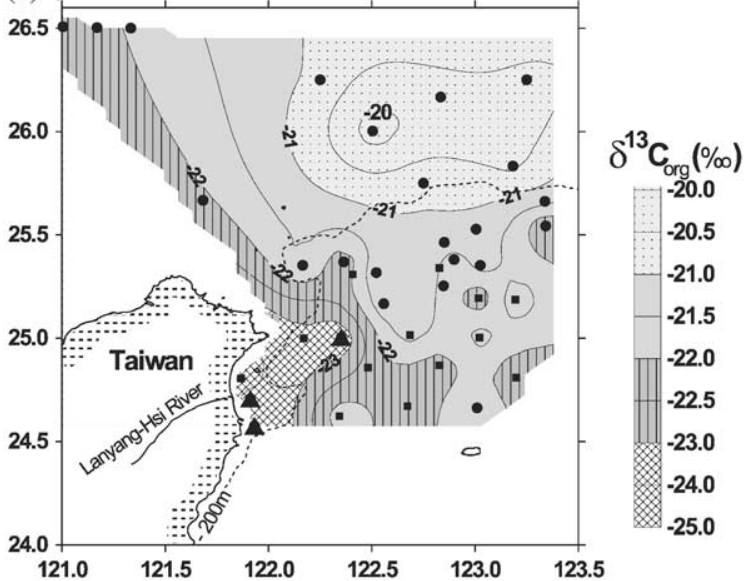

Fig. 5. The same as Fig. 3 except for $\delta^{13} \mathrm{C}_{\text {org }}$ in sediments. Solid squares in the lower panel represent data from Chen (1992).

understandable that the sedimentary organic carbon in this region is predominantly terrigenous and, therefore, has a low $\delta^{13} \mathrm{C}_{\text {org }}$ value; the low TOC content is due to mineral dilution effect, which is common in sediments from mountainous watersheds (Kao and Liu, 1996).

The $\delta^{15} \mathrm{~N}$ values of surficial sediments range from $3.4 \%$ to $6.3 \%$, with most values lower than $5 \%$. The $\delta^{15} \mathrm{~N}$ values greater than $5.0 \%$ exist mainly in a narrow band at the southeastern edge of the ECS shelf (Fig. 6a), where Kuroshio intrudes onto the shelf (Chao, 1991; Tang et al., 1998, 2000; Liang et al., 2003). The slightly elevated $\delta^{15} \mathrm{~N}$ value in the outer shelf is a clear indication of marine origin (Peters et al., 1978). Against rather uniform $\delta^{15} \mathrm{~N}$ values around $4.5 \%$
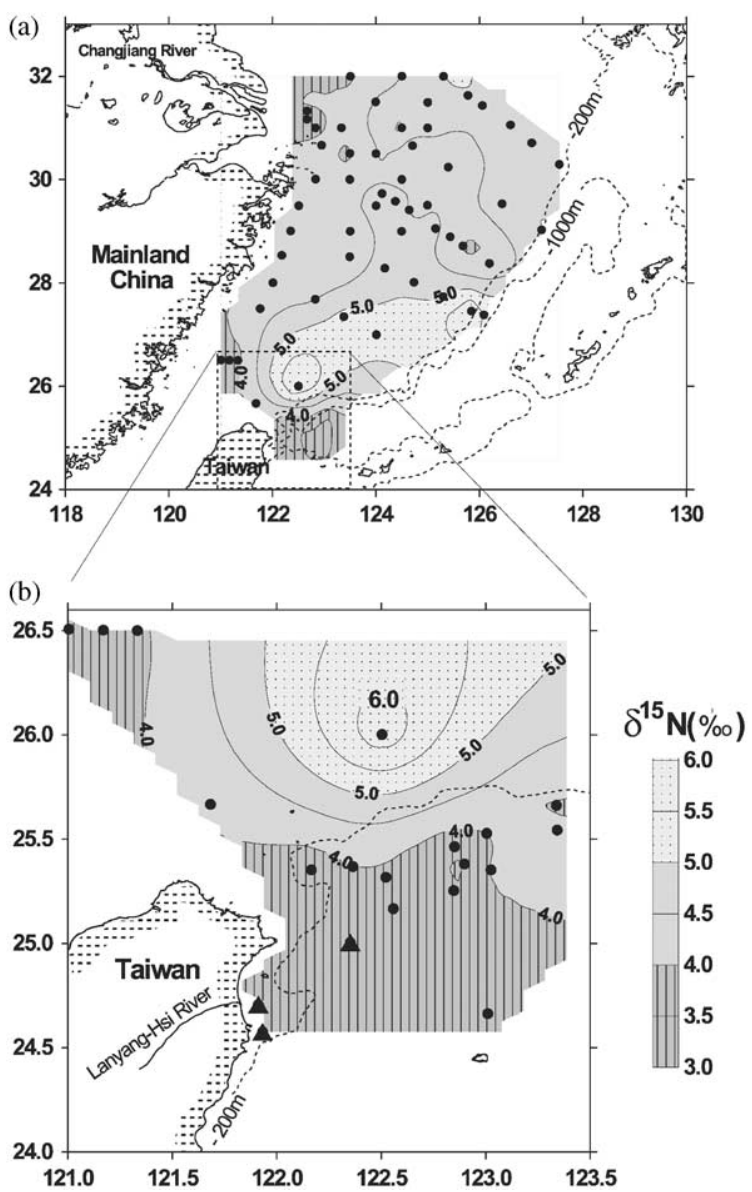

Fig. 6. The same as Fig. 3 except for $\delta^{15} \mathrm{~N}$ of nitrogen in sediments.

over the middle and outer shelves, the inner shelf shows relatively low $\delta^{15} \mathrm{~N}$ values; so does the SOT (Fig. 5b).

\section{Discussion}

In order to determine the most important one among potential sources for the sedimentary organic matter in the SOT, we compare the ${ }^{13} \mathrm{C}_{\text {org }}-{ }^{15} \mathrm{~N}$ compositions of sediments from the ECS shelf and the SOT, the suspended particulate matter in the Lanyang-Hsi River and coastal sediments off its mouth. The dual isotope composition plot (Fig. 7) shows distinctive isotopic composition fields for the inner shelf and for the 


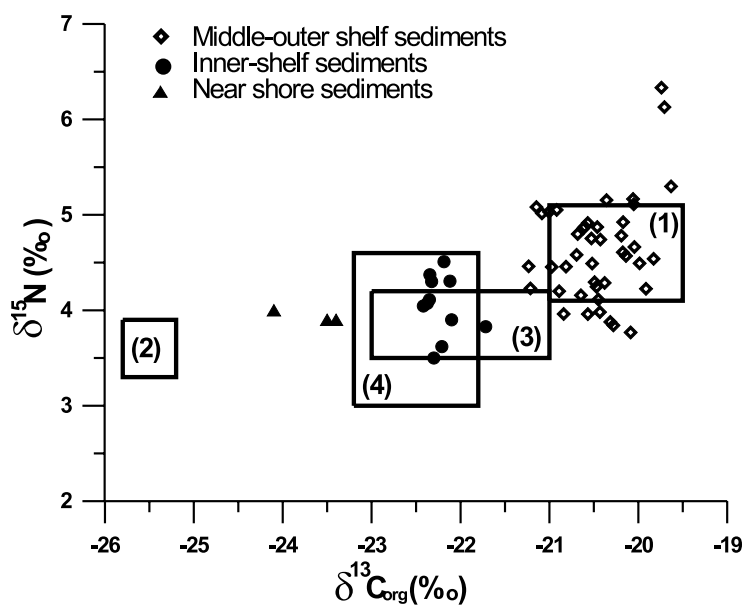

Fig. 7. The $\delta^{13} \mathrm{C}_{\mathrm{org}}-\delta^{15} \mathrm{~N}$ plot of the potential sources and sedimentary organic matter in the southern Okinawa Trough. Rectangle - (1), (2), (3) and (4) represents the isotopic composition field of marine endmember, riverine POM, SOT sediments, and trapped material collected at $\mathrm{SST}_{1}$ and $\mathrm{SST}_{2}$, respectively.

mid-outer shelf. The inner shelf, whose sediments are characterized by higher TOC $\%(>0.5 \%)$ and lower $\delta^{13} \mathrm{C}_{\text {org }}$ values $(<-21.5 \%)$, has a width of roughly $100 \mathrm{~km}$ and is marked out in Fig. 2a. Although the inner shelf sediments mainly originate from the Changjiang (Mckee et al., 1983), their $\delta^{13} \mathrm{C}_{\text {org }}$ values are not characteristic of typical terrigenous organic matter, indicating the reworking and addition of marine organic matter. In the following, we refer to the inner-shelf sediments as a distinctive source of sedimentary organic matter rather than an alias of the Changjiang-discharged materials. The $\delta^{13} \mathrm{C}_{\mathrm{org}}$ values $(-21.4 \%$ to $-19.5 \%$ ) found in the mid-outer shelf sediments agree with the range of POM observed for the latitude of $20-25^{\circ} \mathrm{N}(-21.0$ to $-19.5 \%$; Goericke and Fry, 1994). The $\delta^{15} \mathrm{~N}$ values found in the midouter shelf have a mean value of $4.6 \pm 0.5 \%$, which is similar to that of the upwelled nitrate $\left(\delta^{15} \mathrm{~N}=4.7 \pm 0.6 \%\right.$ o $)$ observed in the southern ECS (Liu et al., 1996). As mentioned earlier, the slightly elevated $\delta^{13} \mathrm{C}_{\text {org }}$ values in the mid-outer shelf may be attributable to organic matter derived from $\mathrm{C}_{4}$ plants. However, the associated $\delta^{15} \mathrm{~N}$ values are typical of marine origin rather than terrestrial characteristics; the observed $\delta^{15} \mathrm{~N}$ values for $\mathrm{C}_{4}$ plants on Taiwan were -4.1 to $-2.6 \%$ as reported by Kao and Liu (2000). Therefore, the dual isotope compositions strongly suggest that sedimentary organic matter in the mid-outer shelf is mainly of marine origin. Since the outcropping area of the nitrate-laden water is quite limited (Hsu et al., 2000), we assume $100 \%$ uptake (i.e. no biological fractionation) of the nitrate reaching the euphotic zone along the shelf break, and, therefore, there is little net isotopic shift in the POM pool as a whole. Based on this assumption, $\delta^{15} \mathrm{~N}$ by Liu et al. (1996) and $\delta^{13} \mathrm{C}$ by Goericke and Fry (1994), we derived a composition field for marine endmember (rectangle - (1) in Fig. 7).

For the source sediments from Taiwan (rectangle - (2) in Fig. 7), we plotted the dual isotope compositions (flux weighted mean) of particulate organic carbon and nitrogen $\left(\delta^{13} \mathrm{C}_{\text {org }}=\right.$ $-25.5 \pm 0.3 \%$ and $\delta^{15} \mathrm{~N}=3.6 \pm 0.3 \%$ o) exported from the Lanyang-Hsi watershed (Kao and Liu, 2000). The isotope compositions of riverine POM from other major rivers $\left(\delta^{13} \mathrm{C}_{\mathrm{org}}=-25.0 \pm 0.3 \%\right.$ and $\delta^{15} \mathrm{~N}=3.8 \pm 0.3 \%$ ) on Taiwan are quite similar to those from the Lanyang-Hsi watershed (S. J. Kao, unpublished data).

The composition field for sediments from the SOT (rectangle - (3) in Fig. 7) is plotted from compiled data in this study, which have rather uniform $\delta^{15} \mathrm{~N}$ values ranging from $3.5 \%$ to $4.2 \%$ (this study), and more variable $\delta^{13} \mathrm{C}_{\mathrm{org}}$, ranging from $-21.0 \%$ to $-23.0 \%$ (this study and Chen, 1992). Also plotted are three samples (represented by triangles in Figs. 5b, 6b and 7) near the Lanyang-Hsi River mouth, where the local river loading probably dominates the sediment supply.

The isotope composition of SOT sediments falls between the terrestrial POM from Taiwan on one side of the composition field and sedimentary organic matter of marine origin on the other side (Fig. 7), but it overlaps with those observed for the inner shelf sediments. Although the organic matter deposited in SOT could be a mixture of different fractions of these potential sources, it is conceivable that the inner-shelf sediments is most likely the dominant source for SOT sediments as suggested by the high degree of isotopic similarity. To investigate this possibility, we draw the 

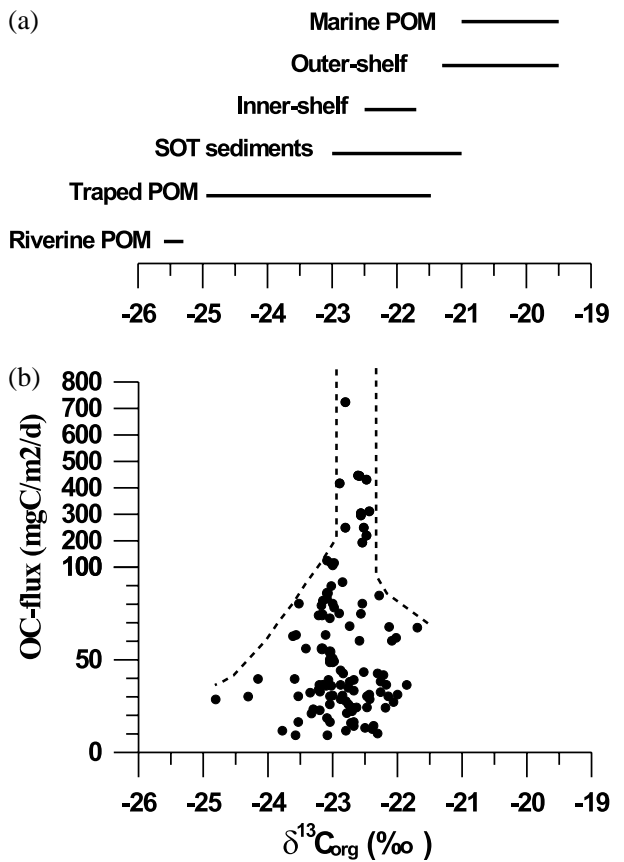

Fig. 8. (a) $\delta^{13} \mathrm{C}_{\mathrm{org}}$ values of different kind of samples. (b) Scatter plots of $\delta^{13} \mathrm{C}_{\text {org }}$ values vs. corresponding organic carbon fluxes (OC-flux) for sinking particles collected in the southern Okinawa Trough (data from Sheu et al. 1999). Note the scale changes in the $y$-axis.

reported sediment trap data of Sheu et al. (1999) for discussion.

For the convenience of comparison, we plot the $\delta^{13} \mathrm{C}_{\text {org }}$ ranges of the SOT sediments and the settling particles collected in the SOT in Fig. 8a. The particulate organic carbon fluxes varied in a wide range, from 10 to $750 \mathrm{mg} \mathrm{C} \mathrm{m}^{-2} \mathrm{~d}^{-1}$ (Fig. 8b). The trapped materials increased significantly with increasing trap depth (Sheu et al., 1999), indicating a strong particle supply from lateral transport as observed in the mid-Atlantic Bight during the SEEP projects (Biscaye et al., 1988, Biscaye and Anderson, 1994). The $\delta^{13} \mathrm{C}_{\text {org }}$ values of the sediment trap samples range from $-24.8 \%$ to $-21.5 \%$, overlapping with the range of the SOT sediments and inner-shelf sediments. Some of the trap materials had $\delta^{13} \mathrm{C}_{\text {org }}$ values (Fig. 8a) very close to that of the POC from the Taiwanese rivers $(-25.5 \pm 0.3 \%$; Fig. 7a). However, these samples all corresponded to rather low organic carbon fluxes (Fig. 8b), suggesting a limited contribution from the Taiwanese rivers as far as POC is concerned.

As the flux increased (e.g. $>150 \mathrm{mg} \mathrm{Cm}^{-2} \mathrm{~d}^{-1}$ in Fig. 8b), the $\delta^{13} \mathrm{C}_{\text {org }}$ values of trapped particles approached a uniform $\delta^{13} \mathrm{C}_{\text {org }}$ value $(-23.0 \%$ to $-22.2 \%$ ). The narrow range overlaps with those of the sedimentary organic matter from the innershelf and the SOT. Because the enhanced fluxes are higher than the background flux $(<50 \mathrm{mg}$ $\mathrm{C} \mathrm{m}^{-2} \mathrm{~d}^{-1}$ ) by factors of $3-15$, they must represent a major fraction of the total depositional flux, and very likely originate from the inner shelf. Heussner et al. (1999) reported similar phenomenon observed in the Cap-Ferret Canyon in the ECOMARGE study. They found that the chemical composition in trapped materials approached the composition of surficial sediments, when total flux increased. They attributed the compositional uniformity to a pre-mixed source material. In our case, this pre-mixed source could be the inner shelf sediments transported across the shelf by the shelf circulation.

On the other hand, the trapped POM could be a mixture of the river-derived POM and sediments from mid-outer shelf as indicated by the compositional field in Fig. 7. If this is indeed the case, it would be necessary to keep the mixing ratio nearly constant for all high flux occasions in order to maintain a rather uniform composition. There seems to be no plausible mechanism to maintain constant mixing ratios between these source materials, whenever the carbon flux is enhanced. Therefore, it is unlikely that the isotopic similarity between the enhanced carbon fluxes and the inner shelf sediments was only fortuitous. Instead, this clearly suggests that the enhance fluxes originate from a premixed single source with rather uniform isotopic composition. The inner-shelf sediment is most likely a major source for the sinking POC in the SOT region.

For further comparison with trapped POM in the adjacent region, we also plotted the dual isotope compositions of sediment trap samples collected at Station $\mathrm{SST}_{1}$ and $\mathrm{SST}_{2}$ (Fig. 2a) reported by Minagawa and Kadota (1994). The $\delta^{13} \mathrm{C}_{\text {org }}$ values obtained from the northern sites match with those from the southern sites surprisingly well (rectangle - (4) in Fig. 7). Moreover, 
the rather uniform $\delta^{15} \mathrm{~N}$ values of surficial sediments from the SOT match almost perfectly with the median value of the $\delta^{15} \mathrm{~N}$ of the northern trap samples. It appears that the northern and the southern parts of the Okinawa Trough may receive similar materials from the shelf despite of their rather large differences in flux magnitude.

The isotopic signal presented above is not the only evidence supporting the inner-shelf sediments as a major source for sediments deposited in the SOT. Elemental analyses of lithogenic materials indicate that the geochemical characteristics of trapped materials in the SOT are much like those of the inner shelf sediments (Hung et al., 1999). An elevated inventory of ${ }^{210} \mathrm{~Pb}\left(300-900 \mathrm{dpm} \mathrm{cm}^{-2}\right)$ on the seafloor in the SOT demands a supply of ${ }^{210} \mathrm{~Pb}$ from about $10 \%$ of the ECS shelf area (Chung and Chang, 1995), which roughly matches the area of the fine-grained sediments in the inner shelf.

The rather long distance, over which the POM must travel to get from the inner shelf to the SOT, deserves comment. It is the fine grain size associated with POM that makes the long-range transport possible. As mentioned earlier, the distributions of TOC and ${ }^{13} \mathrm{C}_{\text {org }}$ resemble the mud distribution in the ECS shelf. Lin and Chen (1996) found a strong positive correlation between fine-grained fraction $(<64 \mu \mathrm{m})$ and TOC in sediments in the southern ECS shelf. This correlation can be explained by the high specific surface area of fine-grained sediments, which have a large capacity for adsorption of organic matter (Mayer, 1994; Keil et al., 1994; Hedges and Keil, 1995). Alternatively, this close correlation also can be attributed to the hydrodynamic equivalence between organic particle and fine-grained sediments (Pedersen and Calvert, 1990). In either case, the distribution pattern of sediments with relatively high TOC content is consistent with the proposed route of sediment transport on the ECS shelf (Liu et al., 2000).

A recent study of circulation in the ECS by a three-dimensional numerical model (Lee and Chao, 2003) supports the notion that the China Coastal Current veers offshore in the northern Taiwan Strait in winter. The modeled flow fields reveal the cyclonic turn of the winter coastal jet in the northern Taiwan Strait and also the northward flowing current in the western Taiwan Strait as shown in Fig. 1. Their numerical experiment of drifters has successfully demonstrated the proposed across-shelf path of particle transport. Similar cross-shelf transport also has been observed near the depocenter off Cape Hatteras on the east coast of the US (DeMaster et al., 1994), where the circulation pattern known as the "Hatteras funnel" is responsible for the seaward export of particulate matter (Rhoads and Hecker, 1994).

It is interesting to note that the $\delta^{13} \mathrm{C}_{\mathrm{org}}$ range of the SOT sediments is slightly higher than the upper limit of the trap samples. Although sediment traps have been widely used to collect materials transported from the shelf to the slope (e.g., Biscaye and Anderson, 1994; Heussner et al., 1999; Chung and Hung, 2000), they are known for their problems with trapping bias and efficiencies, especially in the slope region (Gardner, 1997; Liu et al., 2000). For example, sediment traps may not be able to catch fluid mud in the bottom boundary layer, which is only recently recognized as one of the major forms of cross shelf sediment export (e.g. Trakovski et al., 2000; Ogston et al., 2000). Therefore, the ${ }^{13} \mathrm{C}$-enriched fraction may represent an unaccounted densitydriven transport of the ${ }^{13} \mathrm{C}$-enriched outer-shelf sediments within the bottom boundary layer. On the other hand, it also may represent input of organic matter produced in the overlying water column. The slight isotopic offset between the inner-shelf sediments and the trapped POC at high flux (Fig. 8) may be attributed to selective decomposition and/or the addition of POM from Taiwanese rivers during cross-shelf transportation.

Finally, we will discuss the significance of such a pathway to the export of organic carbon in the continental margin. The total primary production in the East China Sea shelf is estimated to be $115 \mathrm{Mt} \mathrm{Cy}^{-1}$ based on the average given by Gong et al. (2003) and an area of $740000 \mathrm{~km}^{2}$. If $15 \%$ of the fixed carbon is exported from the shelf as organic carbon, the flux is $17 \mathrm{Mt} \mathrm{Cy}^{-1}$, which is on the same order of magnitude as the estimated air 
to sea $\mathrm{CO}_{2}$ flux. How much of the export may be accomplished by the pathway for POC demonstrated here is difficult to assess. The burial flux of organic carbon in the SOT is only on the order of $1 \mathrm{Mt} \mathrm{Cy}^{-1}$ based on a mean burial rate of $2.2 \mathrm{~g}$ $\mathrm{Cm}^{2} \mathrm{y}^{-1}$ (Chen, 1995) and area of $4500 \mathrm{~km}^{2}$. However, it is not clear how much organic carbon gets oxidized before burial or how much fine organic matter gets swept away by the strong current of the Kuroshio flowing in the Okinawa Trough. Further study is warranted to investigate these processes.

\section{Summary and conclusions}

Elemental and isotopic analyses of decarbonated surficial sediments from the East China Sea shelf and the southern Okinawa Trough reveal a similar spatial pattern in the distributions of total organic carbon content, its isotopic composition and nitrogen content. The coastal belt of relatively high total organic carbon contents in sediments and low $\delta^{13} \mathrm{C}_{\text {org }}$ values extends southward from the Changjiang mouth along the coast and veers offshore towards the southern Okinawa Trough in the southern East China Sea near Taiwan. This spatial pattern resembles the mud distribution, indicating the close association between sedimentary organic matter and fine-grained sediments.

The $\delta^{13} \mathrm{C}_{\mathrm{org}}-\delta^{15} \mathrm{~N}$ compositions of surficial sediments in the southern Okinawa Trough $(-22.0 \pm 1 \%$ and $3.9 \pm 0.4 \%$, which represent compositional ranges) falls between the compositional fields of the riverine particulate organic matter from Taiwan $(-25.5 \pm 0.3 \%$ and $3.6 \pm 0.3 \%$ ) and sediments from the mid-outer shelf of the East China Sea $(-20.5 \pm 0.9 \%$ and $5.1 \pm 1.3 \%$ ) , but overlaps with that of the inner shelf sediments $(-22.0 \pm 0.4 \%$ and $4.0 \pm 0.5 \%)$, which is probably the major source of sedimentary organic matter in the southern Okinawa Trough. This notion is further supported by isotopic data of sediment trap samples collected in the southern Okinawa Trough that the $\delta^{13} \mathrm{C}_{\text {org }}$ values $(-22.8 \pm 0.2 \%)$ of sinking particles at high flux are close to those found in the inner shelf. The long range transport of fine-grained sediments facilitated by the shelf circulation is probably responsible for the delivery of sedimentary organic matter from the inner shelf to the southern Okinawa Trough. It is difficult to assess how significant this pathway can contribute to the carbon export in the continental margin, because little is known of the fraction of organic carbon oxidized or swept away before burial in the SOT.

\section{Acknowledgements}

This study was supported by the grant NSC 902611-M-002-041-OP3 from the National Science Council of the Republic of China. We thank the crew of the R/V Ocean Researcher 1 for sampling assistance. We thank Dr. F. K. Shiah for useful discussion and comments. This is NCOR contribution no. 47.

\section{Appendix}

Sampling location, overlying water depth, total organic carbon, total nitrogen and isotopic compositions are given in Table 1.

\section{References}

Aitkenhead, J.A., McDowell, W.H., 2000. Soil C/N ratios as a predictor of annual riverine DOC flux at local and global scales. Global Biogeochemical Cycles 14 (1), 127-138.

Beardsley, R.C., Limeburner, R., Yu, H., Cannon, G.A., 1985. Discharge of the Changjiang (Yangtze River) into the East China Sea. Continental Shelf Research 4, 57-76.

Biscaye, P.E., Anderson, R.F., Deck, B.L., 1988. Fluxes of particle and constituents to the eastern United States continental slope and rise: SEEP-I. Continental Shelf Research 8, 855-904.

Biscaye, P.E., Anderson, R.F., 1994. Fluxes of particulate matter on the slope of the southern Mid-Atlantic Bight: SEEP-II. Deep Sea Research II 41, 459-509.

Chang, F.Y., Kao, S.J., Liu, K.K., 1991. Analysis of organic and carbonate carbon in sediments. Acta Oceanographica Taiwanica 27, 140-150 (In Chinese.). 
Chao, S.Y., 1991. Circulation of the East China Sea, a numerical study. Journal of Oceanographic Society of Japan 46, 273-295.

Chen, C.T.A., Wang, S.L., 1999. Carbon dioxide and related parameters in the East China Sea. Journal of Geophysical Research 104 (20), 675-686.

Chen, M.C., 1992. Stable carbon isotope and organic geochemistry of marine sediments off northeastern Taiwan. M.Sc. Thesis, National sun Yat-sen University, Kaohsiung, Taiwan, 83pp. (In Chinese.)

Chen, S.K., 1995. Sediment accumulation rates and organic carbon deposition in the East China Sea continental margin sediments. M.Sc. Thesis, National Taiwan University, Taipei, Taiwan. (In Chinese.)

Chuang, W.S., 1985. Dynamics of subtidal flow in the Taiwan Strait. Journal of Oceanographic Society of Japan 41, 65-72.

Chung, Y.C., Chang, W.C., 1995. ${ }^{210} \mathrm{~Pb}$ fluxes and sedimentation rates on the lower continental slope between Taiwan and the South Okinawa Trough. Continental Shelf Research 5, 149-164.

Chung, Y.C., Hung, G.W., 2000. Particulate fluxes and transports on the slope between the southern East China Sea and the South Okinawa Trough. Continental Shelf Research 20 (4-5), 571-598.

DeMaster, D., Pope, R.H., Levin, L.A., Blair, N.E., 1994. Biological mixing intensity and rates of organic carbon accumulation in North Carolina slope sediments. Deep Sea Research II 41, 735-754.

Gardner, W.D., Biscaye, P.E., Richardson, M.J., 1997. A sediment trap experiment in the Vema Channel to evaluate the effect of horizontal particle fluxes on measured vertical fluxes. Journal of Marine Research 55, 995-1028.

Goericke, R., Fry, B., 1994. Variations of marine plankton $\delta^{13} \mathrm{C}$ with latitude, temperature, and dissolved $\mathrm{CO}_{2}$ in the world ocean. Journal of Neurology 8, 85-90.

Gong, G.-C., Wen, Y.-H., Wang, B.-W., Liu, G.-J., 2003. Seasonal variation of chlorophyll $a$ concentration, primary production and environmental conditions in the subtropical East China Sea. Deep-Sea Research II, this issue

Goni, M.A., Ruttenberg, K.C., Eglinton, T.I., 1998. A reassessment of the sources and importance of land-derived organic matter in surface sediments from the Gulf of Mexico. Geochemica et Cosmochimica Acta 62, 3055-3075.

Hedges, J.I., Quay, P.D., Richey, J.E., Devol, A.H., Santos, U.M., 1986. Compositions and fluxes of particulate organic material in the Amazon River. Limnology Oceanography 31 (4), 717-738.

Hedges, J.I., Keil, R.G., 1995. Sedimentary organic matter preservation: an assessment and speculative synthesis. Marine Chemistry 49, 81-115.

Heussner, S., Madron, X.D., Radakovitch, O., Beaufort, L., Biscaye, P.E., Carbonne, J., Delsaut, N., Etcheber, H., Monaco, A., 1999. Spatial and temporal patterns of downward particle fluxes on the continental slope of the Bay of Biscay (northeastern Atlantic). Deep Sea Research II 46 (10), 2101-2146.
Hsu, S.C., Lin, F.J., Jeng, W.L., Tang, T.Y., 1998. The effect of a cyclonic eddy on the distribution of lithogenic particles in the southern East China Sea. Journal of Marine Research 56, 813-832.

Hsu, M.K., Liu, A.K., Liu, C., 2000. A study of internal waves in the China Seas and Yellow Sea using SAR. Continental Shelf Research 20, 389-410.

Hu, D., 1984. Upwelling and sedimentation dynamics I: the role of upwelling in sedimentation in the Yellow Sea and East China Sea. Chinese Journal of Oceanology and Limnology 2 (1), 12-19.

$\mathrm{Hu}$, D., Saito, Y., Kempe, S., 1998. Sediment and nutrient transport to the coastal zone. In: Galloway, J.N., Melillo, J.M. (Eds.), Asia Change in the Context of Global Climate Change, IGBP Book Series. Cambridge University Press, Cambridge, pp. 245-270.

Hung, J.J., Lin, C.S., Hung, G.W., Chung, Y.C., 1999. Lateral transport of lithogenic particles from the continental margin of the southern East China Sea. Estuarine, Coastal and Shelf Science 49 (Article No. ecss. 1999.0520).

Ikehara, K., 1995. Depositional pattern of the Okinawa Trough as revealed by $3.5 \mathrm{kHz}$ sub-bottom profiler and cored data. In: Tsunogai, S., et al. (Ed.), Global Fluxes of Carbon and its Related Substances in the Coastal Sea-Ocean-Atmosphere System. M. \& J. International, Yokohama, Japan, pp. 26-31.

Iseki, K., Okamura, K., Tsuchiya, Y., 1995. Seasonal variability in particle distributions and fluxes in the East China Sea. In: Tsunogai, S., et al. (Ed.), Global Fluxes of Carbon and its Related Substances in the Coastal Sea-OceanAtmosphere System. M. \& J. International, Yokohama, Japan, pp. 58-62.

Jan, S., Chern, C.S., Wang, J., 1998. A numerical study of currents in the Taiwan Strait during winter. Terrestrial Atmospheric and Oceanic Sciences 9 (4), 615-632.

Kao, S.J., Liu, K.K., 1996. Particulate organic carbon export from a subtropical mountainous river (Lanyang-Hsi) in Taiwan. Limnology and Oceanography 41 (8), 1749-1757.

Kao, S.J., Liu, K.K., 2000. Stable carbon and nitrogen isotope systematics in a human-disturbed watershed (Lanyang-Hsi) in Taiwan and the estimation of biogenic particulate organic carbon and nitrogen fluxes. Global Biogeochemical Cycles 14 (1), 189-198.

Kao, S.J., Liu, K.K., 2000. Estimating the suspended sediment load by using the historical hydrometric record from the Lanyang-Hsi watershed. Terrestrial Atmospheric and Oceanic Sciences 12 (2), 401-414.

Kao, S.J., Lin, S., Wong, C.H., Lin, I.T., Liu, K.K., 2001. Sedimentary organic carbon and nitrogen contents and their isotopic compositions along two transect on the East China Sea shelf. Geochemical Journal 35, 237-244.

Keil, R.G., Tsamakis, E.C., Fuh, C.B., Giddings, J.C., Hedges, J.I., 1994. Mineralogical and texture controls on the organic composition of coastal marine sediments: hydrodynamic separation using SPLITT-fractionation. Geochemica et Cosmochimica acta 58 (2), 879-893. 
Kukal, Z., 1971. Geology of Recent Sediments. Academic Press, New York, 490p.

Liang, W.D., Tang, T.Y., Yang, Y.J., Ko, M.T., Chaung, W.S., 2003. Upper ocean current around Taiwan. Deep-Sea Research II, this issue

Lee, H.J., Chao, S.Y., 2003. A climatological description of circulation in and around the East China Sea. Deep-Sea Research II, this issue

Lin, S., Liu, K.K., Chen, M.P., Chen, P., Chang, F.Y., 1992. Distribution of organic carbon in the KEEP area continental margin sediments. Terrestrial Atmospheric and Oceanic Sciences 3 (3), 365-378.

Lin, S., Chen, C.M., 1996. Spatial variations of heavy metals in the East China Sea continental shelf surface sediments. Chemistry and Ecology 13, 77-91.

Liu, K.K., Lai, Z.Y., Gong, G.C., Shiah, F.K., 1995. Distribution of particulate organic matter in the southern East China Sea: implication in production and transport. Terrestrial, Atmospheric and Oceanic Sciences 6, 27-45.

Liu, K.K., Su, M.J., Hsueh, C.R., Gong, G.C., 1996. The nitrogen isotopic composition of nitrate in the Kuroshio water northeast of Taiwan: evidence for nitrogen fixation as a source of isotopically light nitrate. Marine Chemistry 54, 273-292.

Liu, K.K., Iseki, K., Chao, S.Y., 2000. Continental margin carbon fluxes. In: Hanson, R.B. (Ed.), The Changing Ocean Carbon Cycle, IGBP book series. Cambridge University Press, Cambridge, pp. 187-239.

Mayer, L.M., 1994. Surface area control of organic carbon accumulation in the continental shelf sediments. Geochemica et Cosmochimica Acta 58 (4), 1271-1284.

Mckee, B.A., Nittrouer, C.A., DeMaster, D.J., 1983. Concepts of sediment deposition and accumulation applied to the continental shelf near the mouth of the Yangtze River. Geology 11, 631-633.

Middelburg, J.J., Nieuwenhuize, J., 1998. Carbon and nitrogen isotopes in suspended matter and sediments from the Schelde Estuary. Marine Chemistry 60, 217-225.

Minagawa, M., Kadota, Y., 1994. Biogeochemistry of carbon and nitrogen in the East China Sea studied by natural ${ }^{13} \mathrm{C}$ and ${ }^{15} \mathrm{~N}$ analyses of particulate matter and sediments. Proceedings of the 1994 Sapporo IGBP Symposium, 14-17 November 1994, Hokkaido University, Japan, pp. 199-206.

Ogston, A.S., Cacchione, D.A., Sternberg, R.W., Kineke, G.C., 2000. Observations of storm and river flood-driven sediment transport on the northern California continental shelf. Continental Shelf Research 20 (16), 2141-2166.

Onstad, G.D., Canfield, D.E., Quay, P.D., Hedges, J.I., 2000. Sources of particulate organic matter in rivers from the continental USA: lignin phenol and stable carbon isotope compositions. Geochemica et Cosmochimica Acta 64 (20), 3539-3546.

Peng, T.H., Hung, J.J., Wannikhof, R., Millero, R.J., 1999. Carbon budget in the East China sea in spring. Tellus 51B, 531-540.
Peters, K.E., Sweeney, R.E., Kaplan, I.R., 1978. Correlation of carbon and nitrogen stable isotope ratios in sedimentary organic matter. Limnology and Oceanography 23, 598-604.

Pedersen, T.F., Calvert, S.E., 1990. Anoxia vs. productivity: what controls the formation of organic-carbon-rich sediments and sedimentary rock? Amer. Assoc. Petrol. Geol. Bull. 74, 454- 466 .

Qu, T., Hu, D., 1993. Upwelling and sedimentation dynamics II: a simple model. Chinese Journal of Oceanology and Limnology 11, 289-295.

Rhoads, D.D., Hecker, B., 1994. Processes on the continental slope off North Carolina with special reference to the Cape Hatteras region. Deep Sea Research II 41, 965-980.

Schubert, C.J., Nielsen, B., 2000. Effects of decarbonation treatment on $\delta^{13} \mathrm{C}$ in marine sediments. Marine Chemistry $72,55-59$.

Sheu, D.D., Jou, W.C., Chen, M.J., Lee, W.Y., Lin, S., 1995. Variations of calcium carbonate, organic carbon and their isotopic compositions in surface sediments of the East China Sea. Terrestrial, Atmospheric, Oceanic Science 6 (1), 115-128.

Sheu, D.D., Jou, W.C., Chung, Y.C., Tang, T.Y., Hung, J.J., 1999. Geochemical and carbon isotopic characterization of particles collected in sediments from the East China Sea continental slope and the Okinawa Trough northeast of Taiwan. Continental Shelf Research 19, 183-203.

Tan, F.C., Cai, D.L., Edmond, J.M., 1991. Carbon isotope geochemistry of the Changjiang Estuary. Estuarine, Coastal and Shelf Science 32, 395-403.

Tang, T.Y., Hsueh, Y., Yang, Y.J., Ma, J.C., 1998. Continental slope flow northeast of Taiwan. Journal of Physical Oceanography 29, 1353-1362.

Tang, T.Y., Tai, J.H., Yang, Y.J., 2000. The flow pattern north of Taiwan and the migration of the Kuroshio. Continental Shelf Research 20, 349-372.

Thornton, S.F., McManus, J., 1994. Application of organic carbon and nitrogen isotopes and $\mathrm{C} / \mathrm{N}$ ratios as source indicators of organic provenance in estuarine systems: evidence from the tay estuary, Scotland. Estuarine, Coastal and Shelf Science 38, 219-233.

Trakovski, P., Geyer, W.R., Irish, J.D., Lynch, J.F., 2000. The role of wave-induced density-driven fluid mud flows for cross-shelf transport on the Eel River continental shelf. Continental Shelf Research 20 (16), 2113-2140.

Tsunogai, S., Watanabe, S., Sato, T., 1999. Is there a "continental shelf pump" for the absorption of atmospheric $\mathrm{CO}_{2}$ ? Tellus 51B, 701-712.

Wada, E.M., Minagawa, H., Mizutani, H., Tsuji, T., Imaizumi, R., Karasawa, K., 1987. Biogeochemical studies on the transport of organic matter along the Otsuchi River watershed, Japan. Estuarine, Coastal and Shelf Science 25, 321-336.

Wang, S.L., Chen, C.T.A., Hong, G.H., Chung, C.S., 2000. Carbon dioxide and related parameters in the East China Sea. Continental Shelf Research 20, 525-544.

Wedeking, K.W., Hayes, J.M., Matzigkeit, U., 1983. Procedure of organic geochemical analysis. In: Schopf, J.W. (Ed.), 
Earth's Earliest Biosphere: Its Origin and Evolution. Princeton University Press, Princeton, NY, pp. 428-441. Willians, P.M., Robertson, K.J., Soutar, A., Griffin, S.M., Druffel, E.R.M., 1992. Isotopic signatures $\left({ }^{14} \mathrm{C},{ }^{13} \mathrm{C},{ }^{15} \mathrm{~N}\right)$ as tracers of sources and cycling of soluble and particulate organic matter in the Santa Monica Basin, California. Progress in Oceanography 30, 253-290.

Zhao, Y., Yan, M., 1994. Geochemistry of sediments of the China Shelf Sea. Science Press, Beijing, China, 203pp. (In Chinese.) 